Egypt. Acad. J. biolog. Sci., 5(2):147-155(2012)

Email: egyptianacademic@yahoo.com

Received: $27 / 7 / 2012$
A. Entomology

ISSN: $1687-8809$

www.eajbs.eg.net

\title{
Role of the lipids on migration rate and infectivity of nematodes.
}

\author{
Ahmed M. Azazy, Saheir F. El-Lakwah* and Heba Yousef \\ Department of Pest Physiology, Plant Protection Research Institute, Agricultural Research Center, \\ Dokki, Giza, Egypt. \\ * Author for correspondence and reprint requests E-mail: sosoellakwah@yahoo.com
}

\section{ABSTRACT}

The present study was recorded the penetration rate, the migration $\%$ and the distance covered by the species [(Steinernema riobrave, Steinernema sp. (S3), Steinernema rarum, Heterorhabditids sp. (Hp2), Heterorhabditids sp. (Hp4) and Heterorhabditids indica)]. In addition, the relation between these activities and the lipid contents of each species were revealed. The authors found that, there are considerable variations in migration rate between entomopathogenic nematodes species and the migration is not affected by the original amount of lipid content in the species. Species that have high lipid contents don't show high migration rate but the infectivity was affected by the amount of lipid contents where the species contain high lipid contents recorded high penetration rate of Galleria mellonella.

Keywords:- Entomopathogenic nematodes, Steinernematidae, Heterorhabditidae, Infective juveniles, Migration rate, Lipid contents, Penetration rate.

\section{INTRODUCTION}

Entomopathogenic nematodes comprise two families, the Steinernematidae and Heterorhabditidae, that are not closely related phylogenetically but which share similar life histories through convergent evolution (Poinar, 1993). Nematodes have qualities that make them potentially suited to become a major factor in the control of soil insects, they actively disperse through soil, they seek out their hosts and they can be mass produced and commercialized (Beekman et al., 1994). Entomopathogenic nematodes associated with Xenorhabdus and Photorhabditis spp. Bacteria, lethal pathogens of soil-inhabiting insects. Nematode infective juveniles occur naturally in the soil where they infect and kill their insect host with in 2 or 3 days and produce 2 or 3 generations in the host. Resulting infective juveniles emerge from host cadaver 1or 2 week later and search for new insect hosts (Akhurst, 1995).

The infective juveniles (IJs) of entomopathogenic nematodes (EPN) are nonfeeding, free-living in soil and depend solely on reserve materials for energy supply (Qiu and Bedding1999). The survival and infectivity of the non- feeding larva of some plant and animal parasitic nematodes is correlated to the levels of energy reserve materials (Elliot, 1954). There is little information concerning the energy metabolism and its relation to survival and infectivity of EPN (Selevan et al., 1993). Successful establishment of nematodes in diverse environments depends upon physiological, behavioral and biochemical adaptations (Nicholas, 1984). These nematodes are faced with a wide array of environmental conditions during the non-feeding infective stage. Migration and host-finding ability are essential processes in their success as biological control agents. The present study yields new information on the relation between lipids and the migration of the entomopathogenic nematodes and highlights the difference between Steinernematidae and Heterorhabitidae and their species in the migration rate. 


\section{MATERIALS AND METHODS}

Six entomopathogenic nematode species were used in the present study, three belong to the family Heterorhabditidae and three to the family Steinernematidae. The six species were obtained from regular culture in the Laboratory of Insect Parasitic Nematodes, Plant Protection Research Institute, Agriculture Research Centre, Egypt. All the used chemicals were supplied by Sigma, Berkley, California, USA, unless otherwise mentioned. Total lipid kit was obtained from El-Gomhoriya Company, Cairo, Egypt. The Equipments, Centrifuge, Beckman, J2 MC, Beckman Co., USA. Spectrophotomer, Beckman, DU 7400 Dual Spectro and stereomicroscope.

Steinernema riobrave, Steinernema sp. (S3), Steinernema rarum, Heterorhabditids sp. (Hp2), Heterorhabditids sp. (Hp4) and Heterorhabditids indica, were cultured in larvae of the wax moth (Galleria mellonella) at $25^{\circ} \mathrm{C}$ according to Woodring and Kaya (1988). Upon collection, IJs were rinsed in deionised water, three times and concentrated to approximately $5000 \mathrm{IJs} / \mathrm{ml}$, and only fresh IJs were used in all the following experiments.

\section{Penetration Rate:-}

Galleria mellonella larvae were exposed to freshly emerged nematode juveniles, at a dose level of $20 \mathrm{IJs} /$ larva in $300 \mu \mathrm{l}$ of distilled water in $1.5 \mathrm{ml}$ Eppendorf tubes, lined with double layer filter paper (Whatman No. 1) and kept at $25^{\circ} \mathrm{C}$, in the dark. After 4-5 days of the infection, according to the species of nematode, at least 10 dead larvae were washed twice with distilled water to remove any nematode juveniles that attached to them, dried and dissected under a stereomicroscope. The number of nematodes inside each larva was counted and the mean of the penetration was calculated.

\section{Dispersal and migration of nematode species.}

This investigation was carried out on newly harvested nematode infective juveniles (IJs) of the six tested nematode species. The column assay (Grewal et al., 1994) was used, plastic tube ( $25 \mathrm{~cm}$ in length and $4 \mathrm{~cm}$ in width), was filled with sandy soil $(10 \% \mathrm{w} / \mathrm{w})$ and divided into five equal sections $(5 \mathrm{~cm}$ length for each) Figure (1). Full grown larvae of G.mellonella were used as bait and kept inside a wire screen cage (1 mm whole size) filled with moist sand, and placed at one end of this plastic tube (B). The prepared tubes were incubated at $25 \pm 1^{\circ} \mathrm{C}$ in the dark, for 24 hours to allow equilibration of any diffuses from the insects throughout the sand column before applying the nematodes. Three thousand IJs in $3 \mathrm{ml}$ distilled water were, applied to the application site of each column and incubated at $25 \pm 1{ }^{\circ} \mathrm{C}$ for 24 hours. After incubation period every sand soil in each section was transferred to a separate petri-dish containing four G. mellonella larvae and dishes were incubated at the same temperature. Mortality percent was recorded, dead larvae were dissected in the end of the $5^{\text {th }}$ day after infection and numbers of adult nematodes were recorded, and migration $\%$ was calculated and the average migration (distance, $\mathrm{cm}$ ) was determined by the following equation:

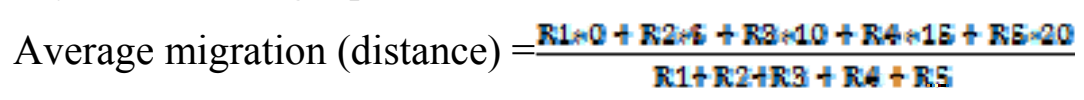

Where R1 (point of inoculation), R2, R3, R4 and R5 are the total number of nematodes recovered from ring 1 , ring 2 , ring 3 , ring 4 and ring 5 , respectively (Chen et al., 2003). 


\section{Determination of Total Lipids.}

Freshly emerged infection juveniles from each of the six tested nematodes were washed three times and concentrated to approximately $5000 \mathrm{IJs} / \mathrm{ml}$. Lipid content was determined in these nematodes. Nematode juveniles were washed and incubated in 15 $\mathrm{ml}$ of $80 \%$ ethanol at $75^{\circ} \mathrm{C}$ for 5 minutes to deactivate degradative enzymes such as phospholipases. The suspension was then cooled and stored in a tight-capped tube after flushing with $\mathrm{N}_{2}$, and stored at $-70^{\circ} \mathrm{C}$ (Abu Hatab, and Gaugler 1997). Lipids were extracted and purified from frozen nematode samples $(0.05-0.1 \mathrm{~g})$ according to Folch et al (1957). Pure vanillin (1.2 g) was dissolved in $20 \mathrm{ml}$ ethyl alcohol and completed to $200 \mathrm{ml}$ with distilled water; $800 \mathrm{ml}$ of concentrated phosphoric acid were added. The solution was stored in dark glass bottle at room temperature. The procedure described by (Knight et al., 1972), was used for the determination of Lipids and measured with spectrophotometer at $525 \mathrm{~nm}$ against a blank.

\section{Statistical Analysis}

Percentage values in the present study were normalized using arcsine transformation. The significance of the main effects was determined by analysis of variance (ANOVA). The significance of various treatments was evaluated by Duncan's multiple range test $(P<0.05)$ (Colman, 2001) according to the statistical methods of Snedecor (1956). All analyses were made using a software package "Costat", a product of Cohort Software Inc., Berkeley, California.

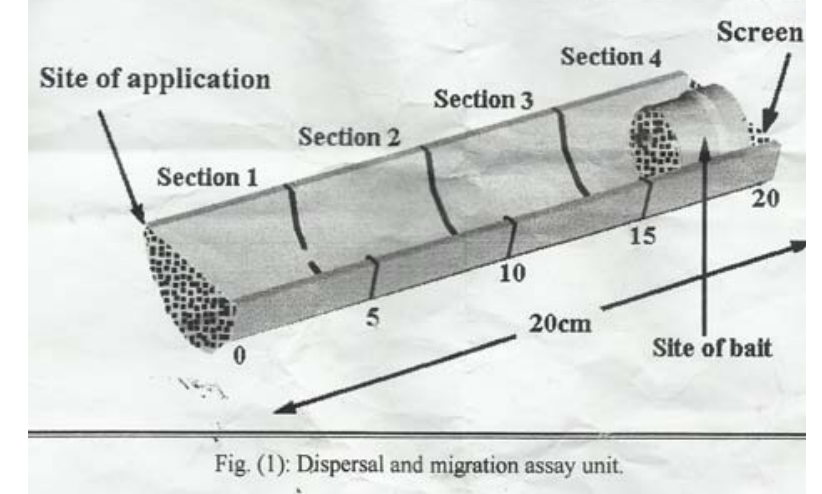

\section{RESULTS}

Data in Figure $(2, \mathrm{~A})$ represented the migration \% of the species Steinernema riobrave, Steinernema sp. (S3), Steinernema rarum, Heterorhabditids sp. (Hp2), Heterorhabditids sp. (Hp4) and Heterorhabditids indica were 4, 21, 28.33, 14, 4.33, $16 \%$, respectively, as we see Steinernema rarum recorded high migration \% and the lowest was recorded by Steinernema riobrave. As shown in figure $(2, \mathrm{~B})$, the average of migration (distance $\mathrm{cm}$.) covered by these species were $0.41,0.63,9.72,1.19,3.84$, $2.5 \mathrm{~cm}$, respectively. We found that $28.33 \%$ of the $S$. rarum migrated $9.72 \mathrm{~cm}$ toward the G. mellonella (the host) and only $4 \%$ of $S$. riobrave migrated $(0.41 \mathrm{~cm})$ toward $G$. mellonella. In the Heterorhabditis Species, we noticed that, $16 \%$ of $H$. indica migrated $2.5 \mathrm{~cm}$, while only $4.33 \%$ of $H p 4$.migrated $3.84 \mathrm{~cm}$. toward the G. mellonella.

Results in figure $(2, \mathrm{C})$ represented the percentage of total lipid for the tested species S. riobrave, (S3), S. rarum, Hp2, Hp4 and H. indica were 29.19, 34.34, $27.30,35.79,30.36,34.49 \%$, respectively. The $S$. rarum recorded the lowest total lipid percentage $27.3 \%$, while it covered longest distance and highest migration percentage. Where the $S$. riobrave covered shortest distance and lowest migration $\%$, it 
recorded $29.19 \%$ of total lipid content. In comparison between the Heterorhabditis species, the species (Hp4) covered longest distance $3.84 \mathrm{~cm}$ and lowest migration\% $4.33 \%$, although it recorded lowest total lipids content $30.36 \%$.

Regarding the mean of penetration rate, presented in figure $(2, \mathrm{D})$, through the Heterorhabditis species the highest penetration rate (11 IJs) was recorded by $(\mathrm{Hp} 2)$ and the lowest penetration rate (2 IJs) was recorded by (Hp4). By comparing between the Steinernema species, the Steinernema sp. (S3) recorded high penetration rate (10IJs) and $S$. rarum recorded the lowest penetration rate (7 IJs). In the six tested species the species have high total lipid percentage showed high mean of penetration rate, so there is directly relationship between the mean of penetration rate and the percentage of total lipids.
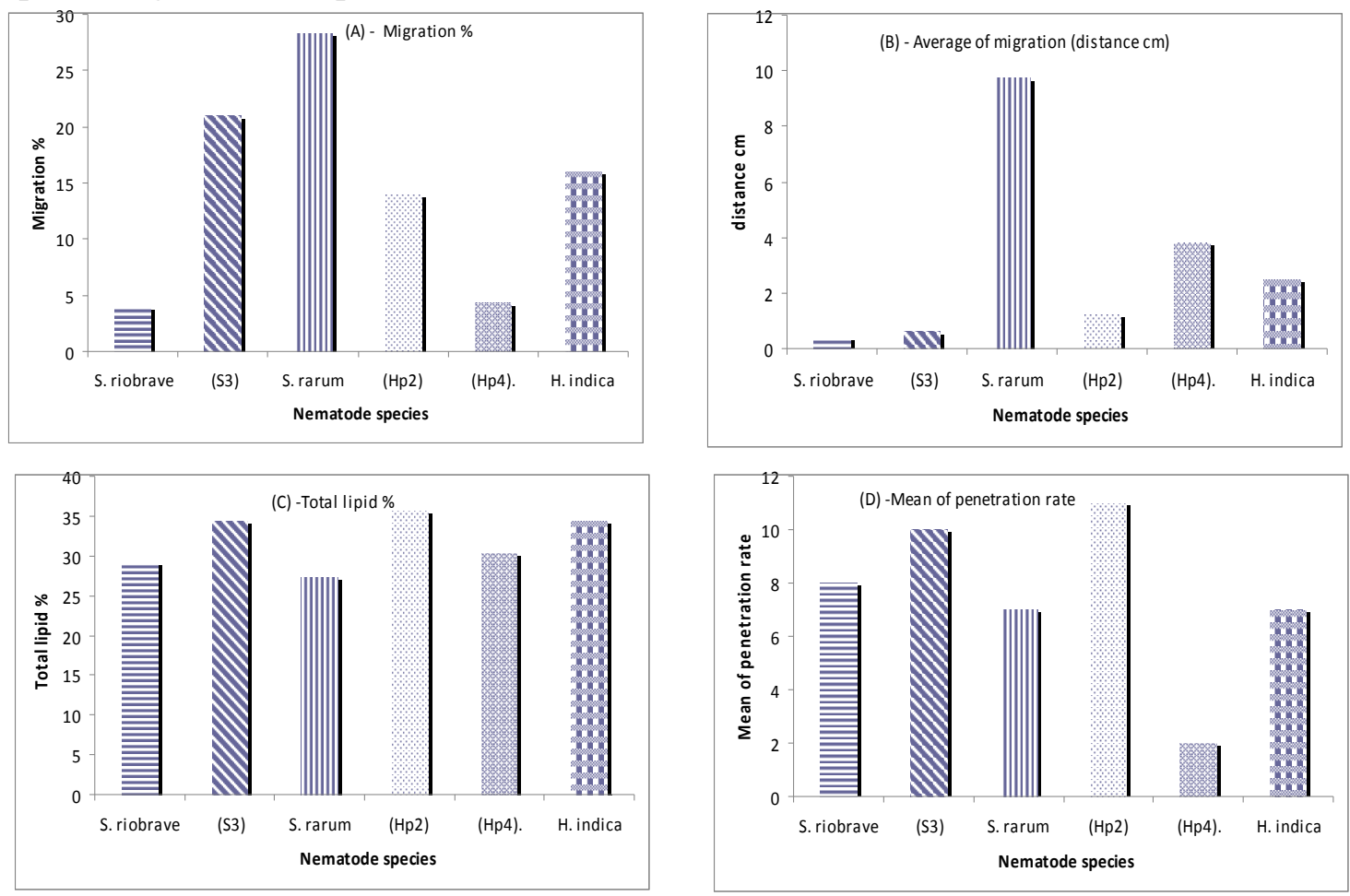

Fig(2): (A)-migration\% (B)- average migration (The distance $\mathrm{cm}$ ), (C)-mean of penetration rate and (D)-total lipid\% Steinernema riobrave, Heterorhabditids sp. (HP2), Steinernema sp. (S3), Heterorhabditids sp. (HP4), Heterorhabditids indica, and Steinernema rarum. Bars indicate Standard error of mean. Columns within treatments annotated with the same letter are not significantly different (Duncan's multiple range; $\mathrm{P}<0.05$ ).

\section{DISCUSSION}

Entomopathogenic nematodes migration is an advantage for both survival and host seeking. Quick migration of nematodes into the soil is essential to escape from solar radiation and desiccation (Gaugler, 1988). Nematodes forage for hosts in several ways, but all of them involve some kind of activity, so they do not necessarily stay where they are applied. Campbell et al., 1996 and Ferguson et al., 1995 found that $H$. bacteriophora strains to be more evenly distributed vertically than either of the Steinernema species tested. Whereas, Georgis and Poinar, 1983; Schroeder and Beavers, 1987 established that S. glaseri and H. bacteriophora move primarily upwards, but also move throughout the soil column. Azazy (2001) showed that the presence of G. mellonella as a host, increase the migration of the IJs of S.c (all) and 
S.c (agriotis) to (29.85 and 21.45\%), respectively. and the IJs of Hp88 was found to move an average net longer of $13.07 \mathrm{~cm}$. than the other tested strains ranged between 3.23 to $12.62 \mathrm{~cm}$. As we see in our result, the distance ranges between 0.41 to $9.72 \mathrm{~cm}$ and the migration rate range between 4 to $28.33 \%$. Also all the isolates which were tested by El-Assal et al., (1997) could kill the host larvae up to $10 \mathrm{~cm}$ within $48 \mathrm{hrs}$. and can extended to $15 \mathrm{~cm}$ within $72 \mathrm{hrs}$. by the two tested species. Miduturi (1997) showed that $S$. feltiae and $S$. affine are able to migrate over $10 \mathrm{~cm}$ within a period of 3 to 7 days; the presence of a host positively affecting their migration. Where Gaugler et al., (1991) mentioned that a wild strain of S. carpocapsae could not locate Galleria larvae placed farther than $3.5 \mathrm{~cm}$.

Our results illustrated that there are variations in the mobile distances and the migration rates between Heterorhabditis and Steinernema species and with in the same genus. This is in agreement with Azazy (2001) who found that the dispersal and migration differ among all tested strains. All nematodes that emerge from a single cadaver are not necessarily the same (Lewis and Gaugler, 1994; Stuart et al., 1996) with respect to behavior (Lewis, 2002). The same author also mentioned that differences in infective juvenile movement and infection rate are related to the presence or absence of the host cadaver. Variability of results obtained concerning persistence, dispersal and infection in soil has often been attributed to insufficient soil moisture (Kain et al., 1981). In the present study, we avoided that by placing the host at the end point as bait, using IJs freshly emerged from the cadaver and keep the soil in each treatment moist during the experiment, thus the variability in the obtained results was mainly due to the differences among the tested species. This variability may be due to the depletion rate of endogenous lipid reserves in the infective juveniles which may differ among the different species (Vänninen, 1990).

Lewis et al., (1995) have mentioned that S. carpocapsae, S. glaseri and $H$, bacteriophora became less mobile with age. Also, Vänninen (1990) found that as nematode juveniles grow older, their ability to migrate, locate a host and penetrate it significantly decreased. The shelf-life of entomopathogenic nematodes has been found to correlate with the relative abundance of stored lipids per dry weight (Bedding et al., 1993; Grewal and Georgis. 1995). Lipids are ideal compounds for long term energy storage, due to their high energy content (Stryer, 1988). In the present investigation, the total lipids for the six species (Steinernema riobrave, Steinernema sp. (S3), Steinernema rarum, Heterorhabditids sp. (Hp2), Heterorhabditids sp. (Hp4) and Heterorhabditids indica,) varied significantly from $27.30 \%$ to $35.79 \%$ and the highest total lipid (35.79\%) percentage was recorded for the Heterorhabditis sp. (HP2). Fitters et al., (1999) found that lipids represented 34$43 \%$ of the dry weight of three isolates of Heterorhabditis sp. where total lipids percentage was $36-40 \%$ in another strain of the same species tested by Lewis et al., (1995), our result investigated the total lipid percentage ranged from 27.30 to $35.72 \%$. Selvan et al., (1993) have recorded that chemical composition of inflictive juvenile entomopathogenic nematodes varied between species. As so we have found that there are considerable variations in migration rate between entomopathogenic nematodes species and this rate of migration is not related to the amount of lipids in the species, in another meaning, nematode species have high amount of lipids must not show high rates of migration. Although we found that infectivity is related to the amount of lipids in the species, i.e., the species with high amount of lipids recorded high penetration to the G. mellonella. So we state here that migration rate of the species of entomopathogenic nematode species is not related to the lipid content but it may be 
affected by the lipid content decline sharply with age than its natural amount in the same species.

These results suggest that infection strategies are likely to be much more complicated than previously known, and that each species may have a strategy that is unique. Within the species belong to Heterorhabditis and Steinernema, there is considerable variation in foraging strategies. The foraging strategies used by infective juveniles to find a host vary along a continuum between ambush and cruise foraging (Lewis et al, 1992, 1993; Campbell and Gaugler, 1993, 1997; Grewal et al., 1994). Nematode infective juveniles are motile, and their search behavior can be divided into two broad categories, crawling, and standing on their tails (i.e. nictation) (Campbell and Gaugler, 1997). Understanding the mechanics of foraging behaviors is the key to constructing predictions of how foraging strategy influences nematode biology and the mobile distance that they move. Cruiser species, such as H. megidis, directionally respond to host cues and can travel for long distances. Ambushers, however, lack any directional response to host cues and are less mobile. (Chen et al, 2003). S. carpocapsae and S. scapterisci for example, spend most of their time in prolonged bouts of motionless nictation which may last several hours, which is typical of ambushing species. Many Steinernema species exhibit jumping behavior, (Campbell and Gaugler, 1993). To jump, nematodes form a loop with their bodies, by contracting the loop, the nematode generates enough stored energy that when the loop is released, they are propelled through the air (Campbell and Kaya, 1999a, b). The frequency of jumping, like standing behaviour, varies among species, and is increased by mechanical contact, air movement, and volatile host cues (Campbell and Kaya, 2000). Lewis et al., (1997) have mentioned that, Steinernema species change their foraging strategy for infecting a host, from ambushers to cruisers. During the ambushing state the nematode juveniles depend mainly upon carbohydrates as energy reserves because they stay motionless. When they change their searching strategy to be cruisers, they begin to utilize their lipid content. The present study shows that both the migration percentage and the distance traveled by entomopathogenic nematodes not related to the original amount of lipid contents but maybe related to the behavior or to the inherited traits in each species.

\section{REFERENCES}

Abu Hatab, M. A. and Gaugler, R. (1997). Fatty acids of Xenorhabdus sp. in response to different growth conditions. J. Appl. Microbiol., 82, 351-358.

Akhurst, R. J. (1995). Bacterial symbionts of entomopathogenic nematodes-the power behind the throne. In,Bedding, R., Akhurst, R. and Kaya, H.(eds) Nematodes and the Biological control of Insect Pests. CSIRO Publications, East Melboune, Australia, pp.127-135.

Azazy, A.M. (2001). Comparative studies between Insect pathogenic nematodes and other Methods in controlling some soil insects fruit tree borers. B.Sc. Fac. Agric., Zagazig University.

Bedding, R. A., Akhurst, R. J. and Kaya, H. K. (1993). Future prospects for entomopathogenic nematodes. In Nematodes and the Biological control of pests, ed. R.Bedding, R.Akhurst and H. Kaya. CSIRO Publications, East Melbourne, Australia pp, 157-170.

Beekman, M. Z. K.; Wiegers G. L. and. Smits P. H. (1994). Biological control of cockchafter larvae (Melolontha melolontha) with the entomopaerthogenic 
nematode Steinernema glasseri. Med. Fac. Landbouww,Univ. Gent59 (2a),411-419.

Campbell, J. F. and Gaugler, R. (1993). Nictation behaviour and its ecological implications in the host search strategies of entomopathogenic nematodes (Heterorhabditidae and Steinernematidae). Behaviour 126, 155-169.

Camp bell, J. F. and Gaugler, R. (1997). Inter-specific variation in entomopathogenic nematode foraging strategy, dichotomy or variation along a continuum? Fund. Appl. Nematol. 20, 393-398.

Campbell, J. F. and Kaya, H. K. (1999a). Mechanism, kinematic performance and fitness consequences of jumping behavior in entomopathogenic nematodes (Steinernema spp.). Can. J. Zool. 77, 1947-1955.

Campbell, J. F. and Kaya, H. K. (1999b). How and why a parasitic nematode jumps. Nature 397,485

Campbell, J. F, and Kaya, H. K. (2000). Influence of insect associated cues on the jumping behavior of entomopathogenic nematodes (Steinernema spp.). Behaviour 137, 591-609.

Campbell, J. F., Lewis, E .E., Yoder, F. and Gaugler, R. (1996). Spatial and temporal distribution of entomopathogenic nematodes in turf. J. Parasitol. 113, 473-482.

Chen, S., HAN, J. LI2, X. and MOENS, M., (2003). Effect of temperature on the pathogenicity of entomopathogenic nematodes (Steinernema and Heterorhabditis spp.) to Delia radicum. Biocontrol 48, 713-724

Colman, A. M. (2001). Duncan's multiple range tests. Dictionary of Psychology. Publ Oxford University.

El-Assal, F. M., El-Garhy, M. F., El-Bishry, M. H. and Abd El-Rahman, R. M.(1997). Biological ecological evaluation of four indigenous heterorhaitid nematodes isolated from Egypt. Egypt. J. Biol. Pest. Control, 7(2), 1997, 61-71.

Elliot, A. (1954). Relationship of aging, food reserves and infectivity of larvae of Axaridia galli. Exp. Parasitol. 3, 307-320.

Ferguson, C. S., Schroeder, P. C. and Shields, E. J. (1995). Vertical distribution, persistence, and activity of entomopathogenic nematodes (Nematoda, Heterorhabditidae and Steinernematidae) in alfalfa snout beetle (Coleoptera, Curculionidae) infested fields. Environ. Entomol. 24, 149-158.

Fitters, P.F.L., Patel, M.N., Griffin, C.T., Wright, D.J. (1999).Fatty acid composition of Heterorhabditis sp. during storage. Comp. Biochem. Physiol. 124: B: 81-88.

Folch, J., Lees, M. and Sloane-Stanly, G. (1957). A simple method for the isolation and purifications of total lipids from animal tissues. J. Biol. Chem., 226, 497-509.

Gaugler, R. (1988). Ecological considerations in the biological control of soilinhabiting insects with entomopathogenic nematodes. Agric. Ecosyst. Environ. 24, 351-360.

Gaugler, R., Campbe, J. F. and Gupta, P. (1991). Characterization and basis of enhanced host finding a genetically improved strain of Steinernema carpocapsae. J. Invertebr. Pathol., 57 (2),234-241.

Georgis, R. and Poinar, G. O. Jr (1983). Effect of soil texture on the distribution and infectivity of Neoa.plecta.na- carpocapsae (Nematoda, Steinernematidae). $J$ Nematol., 15, 308-311.

Grewal, P. and Georgis, R. (1995). Nematode quality Abstracts of the Second International Symposium on Entomopathogenic Nematodes and their Symbiotic Bacteria, October 15-17, Honolulu, Hawaii, USA. 
Grewal, P. S., Lewis, E. E., Gaugler, R. and Campbell, J. F. (1994). Host finding behaviour as a predictor of foraging strategy in entomopathogenic nematodes. Parasitol., 108, 207-215.

Kain,W. M.; Wyeth T. K. and Kale, A. J.( 1981). Preliminary field studies on the use of an indigenous parasitic nematode for the control of porina. Proc. N.Z. Weed Pest Control Conf. 34, 173-175.

Knight, J. A., Anderson and Rode, J. A. (1972). Chemical basis of sulfuricphosphovanillin reaction for estimation of total lipids. Clin. Chem., 18, 199-202.

Lewis, E. E. (2002). Behavioural Ecology In, Gauglar, R. (eds) Entomopathogenic Nematology. CABI Publishing, UK pp. 205-223.

Lewis, E. E. and Gaugler, R. (1994). Entomopathogenic nematode sex ratio relates to strategy. J. Invertebr. Pathol., 64, 238-242.

Lewis, E. E., Campbell, J. F. and Gaugler, R. (1997). The effects of aging on the foraging behaviour of Steinernema carpocapstte (Rhabdita, Steinernematidae). Nematologica 43, 355-362.

Lewis, E. E., Gaugler, R. and Harrison. R. (1992). Entomopathogenic nematode host finding response to host contact cues by cruise and ambush foragers. Parasitol., 105, 309-319.

Lewis, E. E., Gaugler, R. and Harrison, R. (1993). Response of cruiser and ambusher entomopathogenic nematodes (Steinernematidae) to host volatile cues. Can. J. Zool., 11,765-769.

Lewis, E. E., Selvan, S., Campbell, J. F. and Gaugler, R. (1995). Changes in foraging behaviour during the infective juvenile stage of entomopathogenic nematodes. Parasitol., 110, 583-590.

Miduturi, J. S. (1997). Bionomics of naturally occurring entomopathogenic nematodes in Belgium. PhD thesis, University of Ghent, pp 163.

Nicholas, W. L. (1984). The biology of free-living nematodes, $2^{\text {nd }}$ ed. Clarendon Press, Oxford, U.K., p 251.

Poinar, G. O. JR. (1993). Origins and phyletic relationships of the entomopathophilic rhabditids. Heterorhabditis and Steinernema. Fund. Appl. Nematol., 16,333-338

Qiu, L. and Bedding, R. A. (1999). Low temperature induced cryptroectant synthesis by the infective juveniles of Steinernema carpocapsae, its biological significance and the mechanisms involved. Cryo letters, 20, 393-404.

Schroeder, W.J. and Beavers, J. B. (1987). Movement of the entomogenous nematodo of the families Heterorhabditidae and Steinernematidae in soil. J. Nematol., 19, 257-259.

Selvan, S., Gaugler, R., and Lewis, E. E. (1993). Biochemical energy reserves of entompathogenic nematodes. Parasitol., 79, 167-172.

Snedecor, G. W. (1956). Statistical Methods. 5th Ed. Iowa State University College Press, Ames, Iowa, USA.

Stryer, I. (1988). Biochemistry. Freeman, New York

Stuart, R .J., Lewis, E. E. and Gaugler. R. (1996). Selection alters the pattern of emergence from the host cadaver in the entomopathogenic nematode, Steinernema \%laun. Parasitol., 113, 183-189.

Vänninen, I. (1990). Depletion of endogenous lipid reserves in Steinernema feltiae and Heterorhabditis bacteriophora on infectivity. Proc. Int. Colloq. Invertebr. Pathol. Micorob. Control 5, 232.

Woodring, J. L. and Kaya, H. K. (1988). Steinernematid and Heterorhabditid Nematodes, A Handbook of Biology and Techniques. Southern Cooperation Series Bull. pp.331, 30. 


\section{ARABIC SUMMARY}

دور الدهون على معدل هجرة وعدوى النيماتودا الممرضة للحشرات

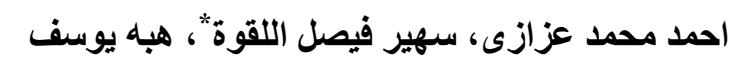

قسم فسيولوجيا الافات ـ معهد بحوث وقايه النباتات_مركز البحوث الزرة اعبه ـالدقىـ الجيزة

لقد تمت دراسة معدل الاختراق، ونسبه الهجرة و المسافة التي تغطيها الأنواع Steinernema) riobrave, Steinernema sp. (S3), Steinernema rarum, Heterorhabditids sp. (Hp2), Heterorhabditids sp. (Hp4) and Heterorhabditids indica)

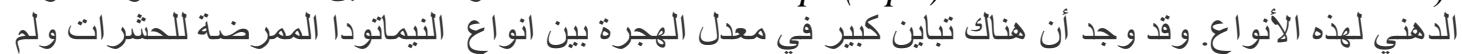

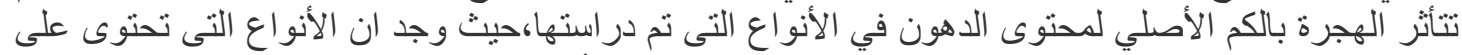

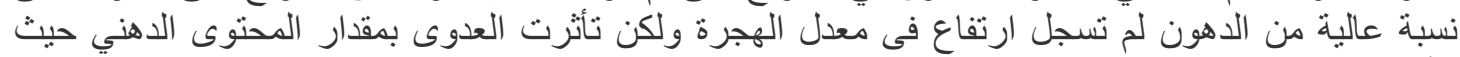

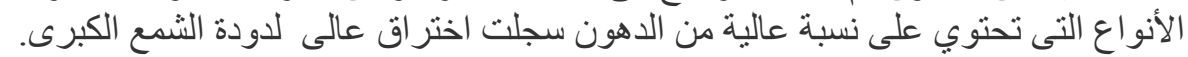

